\title{
Sistem Klasifikasi Jenis Jeruk Impor Menggunakan Metode Klasifikasi Logarithmic Generalized Classifier Neural Network (LGCNN)
}

Orange Import Type Classification System Using Logarithmic Generalized Classifier Neural Network (LGCNN) Classification Method

\author{
Supria ${ }^{1}$, Andi Baso Kaswar ${ }^{2}$ \\ ${ }^{1}$ Politeknik Negeri Bengkalis; Bengkalis, telp +62 (766) 24566 \\ ${ }^{2}$ Universitas Negeri Makassar, Makassar, telp 0411-865677 \\ e-mail: ${ }^{1}$ phiya1287@gmail.com, ${ }^{2}$ kaswar.andi.baso14@mhs.if.its.ac.id
}

\begin{abstract}
Abstrak
Jeruk merupakan salah satu jenis buah yang sering dikonsumsi oleh manusia. Selain karena rasanya yang cukup disukai, jeruk juga dipilih sebagai buah favorit karena manfaatnya yang begitu banyak bagi kesehatan karena kaya akan vitamin C. beberapa manfaat dari buah jeruk antaralain adalah mencegah kanker, menjaga kesehatan jantung dan ginjal, menjaga stamina, membantu kesehatan syaraf, mencegah kerusakan kulit, membantu menjaga system imun dan masih banyak manfaat lainnya. Ada beberapa jenis jeruk yang dapat dibedakan melalui penginderaan. Namun jika orang tidak mengerti jenis jeruk maka sulit untuk membedakan jenis jeruk tersebut. Pada penelitian ini diusulkan Sistem klasifikasi jenis jeruk impor menggunakan metode klasifikasi LGCNN. Ada beberapa tahapan pada sistem yang dirancang yaitu preprocessing, segmentasi, ekstraksi fitur dan klasifikasi. Sistem ini dirancang untuk mengetahui jenis jeruk impor seperti jeruk ponkam, jeruk navel, jeruk valencia dan jeruk santang. Dari hasil ujicoba yang telah dilakukan menunjukkan sistem ini dapat mengklasifikasikan jenis jeruk dengan tingkat akurasi $95.75 \%$.
\end{abstract}

Kata kunci: Jenis jeruk impor, klasifikasi, ekstraksi fitur, LGCNN

\begin{abstract}
Orange is one type of fruit that is often consumed by human. Apart from being liked quite well, oranges are also chosen as a favorite fruit because the benefits are so much for health because it is rich in vitamin $C$. Some of the benefits of citrus fruits include preventing cancer, maintaining heart and kidney health, maintaining stamina, helping nerve health, preventing skin damage, helps maintain the immune system and many other benefits. There are several types of oranges that can be distinguished by sensing. But if people do not understand the type of orange, it is difficult to distinguish the type of orange. In this study, the classification system for imported oranges types was proposed using the LGCNN classification method. There are several stages in the system that are designed, namely preprocessing, segmentation, feature extraction and classification. This system is designed to find out the types of imported oranges such as oranges ponkam, navel oranges, valencia oranges and orange oranges. From the results of tests that have been conducted, this system can classify citrus types with an accuracy rate of $95.75 \%$.
\end{abstract}

Keywords: Orange type import, classification, feature extraction, LGCNN 


\section{PENDAHULUAN}

Jeruk merupakan salah satu jenis buah yang sering dikonsumsi oleh manusia. Selain karena rasanya yang cukup disukai, jeruk juga dipilih sebagai buah favorit karena manfaatnya yang begitu banyak bagi kesehatan karena kaya akan vitamin C. beberapa manfaat dari buah jeruk antaralain adalah mencegah kanker, menjaga kesehatan jantung dan ginjal, menjaga stamina, membantu kesehatan syaraf, mencegah kerusakan kulit, membantu menjaga system imun dan masih banyak manfaat lainnya.

Kebutuhan akan buah jeruk saat ini cukup tinggi sehingga setiap hari diperlukan pemasokan buah jeruk. Kebutuhan yang tinggi mengakibatkan produsen jeruk untuk bertindak lebih cepat agar produk dapat sampai dengan cepat kepada konsumen. Biasanya produsen jeruk tidak hanya mengembangkan satu atau dua jenis jeruk saja, melainkan beberapa jenis buah jeruk. Sebelum di salurkan ke konsumen tentunya harus dilakukan penyortiran terlebih dahulu terhadap jenis buah jeruk yang cukup banyak. Masalah yang muncul kemudian adalah walaupun berbeda jenis, tiap jenis jeruk memiliki warna dan bentuk yang hampir sama. Selain itu, Penyortiran biasanya dilakukan secara manual dengan bantuan tenaga manusia namun hal ini rawan terhadap kesalahan penyortiran sehingga dibutuhkan suatu teknologi/perangkat lunak yang bisa membantu proses penyortiran jenis buah jeruk. Sistem yang dibutuhkan adalah sistem yang mampu melakukan klasifikasi jenis jeruk secara akurat.

Penelitian tentang segmentasi dan klasifikasi untuk mendiagnosis jenis penyakit kulit telah dilakukan [1]. Sistem ini dibuat dengan menggunakan fitur warna dan fitur tekstur dengan metode klasifikasi KNN yang dibandingkan dengan SVM. Fitur yang digunakan adalah mean, skewness, standard deviation, dan variance. Sistem ini mampu mengklasifikasikan jenis penyakit kulit, sehingga dapat diterapkan untuk klasifikasi jenis jeruk impor pada penelitian ini. Selain itu penggunaan LGCNN dapat meminimalisir jumlah iterasi pada klasifikasi [2]. LGCNN menggunakan fungsi logarithmic sehingga dapat mengurangi jumlah iterasi untuk mencapai error minimal. Sehingga LGCNN dapat digunakan untuk metode klasifikasi jenis jeruk impor untuk mendapatkan akurasi yan lebih akurat.

Pada penelitian ini diusulkan Sistem klasifikasi jenis jeruk impor menggunakan metode klasifikasi LGCNN. Sistem ini dibuat dengan mengkombinasikan fitur warna orde 1 (mean, skewness, standard deviation, dan variance), fitur warna orde 2 (ASM, CON, COR, VAR, IDM dan ENT) dan fitur bentuk (geometric) dengan menggunakan metode LGCNN untuk mendapatkan hasil klasifikasi jenis jeruk impor yang lebih akurat. Dengan adanya sistem ini, diharapkan dapat mengklasifikan jenis jeruk impor dengan akurasi yang lebih akurat. Beberapa kelebihan dengan bantuan perangkat lunak dalam penyortiran jenis jeruk adalah konsisten dan akurat sehingga perangkat lunak klasifikasi jenis jeruk dapat digunakan untuk membantu peran karyawan dalam melakukan penyortiran jenis jeruk.

\section{METODE PENELITIAN}

A. Jeruk

Varietas jeruk impor di indonesia terdapat beberapa jenis diantaranya adalah jeruk ponkam, jeruk navel, jeruk valencia dan jeruk santang.

Jeruk ponkam merupakan jeruk impor. jeruk ini biasa juga disebut sebagai jruk mandarin. Ciriciri dari jeruk ponkam ini ukurannya lebih kecil disbanding dengan jeruk impor lainnya. Memiliki tekstur dengan bintik gelap dibagian kulit buah. Dan dari segi warna, jeruk ini memiliki warna kuning. Contoh jeruk ponkam dapat dilihat pada gambar 1. 


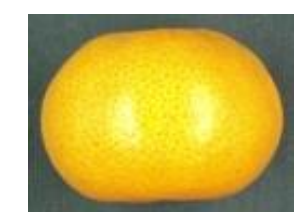

Gambar 1 Jeruk ponkam

Untuk jeruk jenis sunkist ini, memang dikenal lebih baik dikelasnya. Bentuknya bulat dan warna kulit Navel memiiki warna orange lebih pekat. Dan yang paling utama serta lebih mudah untuk membedakannya, anda bisa perhatikan bulatan yang berlubang (mirip pusar) pada bagian bawah buahnya. Contoh jeruk navel dapat dilihat pada gambar 2.

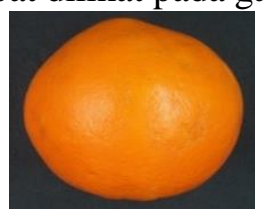

Gambar 2 Jeruk navel

Bentuk buah jeruk valencia hampir mirip dengan jeruk navel yaitu sama-sama bulat tetapi warna kulit valencia berbeda dengan jeruk navel yaitu berwarna orange dan bertekstur kulit licin. Dan perbedaannya yang paling mencolok ialah bila jeruk valecia bulatan pada bagian bawah buah lebih kecil dan tak berlubang. Contoh jeruk valencia dapat dilihat pada gambar 3 .

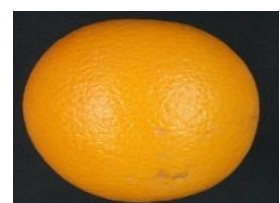

Gambar 3 Jeruk valencia

Bentuk dari jeruk santang ini kecil. Warna kulitnya orange. Contoh jeruk santang dapat dilihat pada gambar 4.

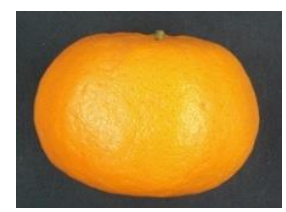

Gambar 4 Jeruk santang

B. Ruang warna La*b*

Comission Internationale de l'Eclairage/International Commission on Illumination (CIE) yang merupakan Salah satu organisasi internasional yang cukup peduli dengan hal-hal yang berkaitan dengan pengekspresian warna-warna numeric merekomendasikan sebuah kombinasi illuminasi/pengamatan dan ruang warna tertentu $\left(\mathrm{La}^{*} \mathrm{~b}^{*}\right)$ yang bertujuan pada standardisasi definisi warna dan memberikan perbedaan warna lebih seragam dalam kaitannya dengan perbedaan visual [3], [4]. Ruang warna seperti terlihat pada Gambar 5. 


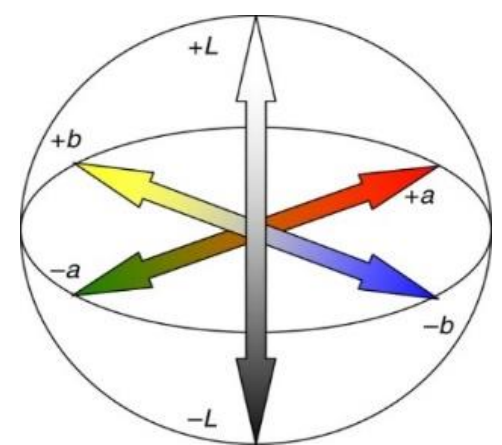

Gambar 5 Ruang warna La*b*

Pada ruang warna $\mathrm{La}^{*} \mathrm{~b}^{*}$, seperti terlihat pada Gambar 2.5, L menunjukkan nilai lightness, nilainya berkisar antara nilai 0 (hitam) hingga 100 (putih). $a^{*}$ dan $b^{*}$ adalah koordinat kromatisitas [3]. $\mathrm{a}^{*}$ dan $\mathrm{b}^{*}$ menunjukkan arah warna, yakni $+\mathrm{a}^{*}$ adalah koordinat merah, $-\mathrm{a}^{*}$ adalah koordinat hijau, $+\mathrm{b}^{*}$ adalah koordinat kuning dan $-\mathrm{b}^{*}$ adalah koordinat biru. Pusat dari ruang warna ini adalah akromatis, ketika nilai $a^{*}$ dan $b^{*}$ meningkat dan titik bergerak keluar dari pusat maka nilai saturation warna meningkat.

\section{Preprocessing}

Tahapan preprocessing bertujuan untuk menghasilkan citra yang lebih baik untuk selanjutnya dilakukan proses segmentasi [5][3]. Dalam kasus klasifikasi jenis jeruk diperlukan proses preprocessing citra jeruk untuk menghasilkan citra jeruk yang lebih baik sehingga bisa dilakukan proses segmentasi dengan baik. tahapan preprocessing berupa perubahan ruang warna citra input dari RGB ke ruang warna $\mathrm{LA}^{*} \mathrm{~B}^{*}$.

\section{Segmentasi menggunakan K-Means}

Segmentasi merupakan proses pengolahan citra dengan tujuan mendapatkan objek pada gambar. Proses ini memisahkan antara objek dengan background, yang ditransformasi kedalam image biner dalam nilai 0 dan 1, dengan menganggap nilai 1 sebagai objek dan nilai 0 sebagai background [6][5][1][7].

K-means clustering merupakan metode yang digunakan untuk mengelompokkan data berdasarkan jarak kemiripan yang paling dekat. Segmentasi menggunakan k-means dengan mengelompokkan warna yang memiliki tingkat kemiripan yang tinggi. Segmentasi gambar menggunakan k-means dalam ruang warna HSV[6] [8]diimplementasikan untuk menghasilkan clustering dari histogram warna dan histogram grayscale.

\section{E. Jenis fitur}

Dalam rangka melakukan proses klasifikasi maka diperlukan data berkaitan dengan fitur jeruk. Fitur yang digunakan harus bersifat unik untuk tiap jenis jeruk. Fitur adalah potongan informasi yang relevan untuk menyelesaikan pekerjaan komputasi yang berhubungan dengan aplikasi tertentu. Pada kasus identifikasi jenis jeruk, maka fitur bentuk, warna dan tekstur dapat digunakan.

1. Fitur Geometrik

Ekstraksi ciri berdasarkan fitur geometric sering digunakan untuk mengenali sebuah objek berdasarkan bentuknya. Pada penelitian ini fitur geometric yang digunakan berupa luas area objek, keliling, dan circularity jeruk.

2. Ekstraksi ciri orde 1

Ekstraksi ciri orde pertama merupakan metode pengamatan ciri yang didasarkan pada 
karakteristik histogram citra (warna). Histogram menunjukkan probabilitas kemunculan nilai derajat intensitas piksel pada suatu citra. Dari nilai nilai pada histogram yang dihasilkan, dapat dihitung beberapa parameter ciri orde pertama, antara lain adalah mean, skewness, variances, kurtosis, dan entropy.

a. Mean $(\mu)$

Menunjukkan ukuran dispersi dari suatu citra.

$$
\mu=\sum_{n} f_{n} p\left(f_{n}\right)
$$

Dimana fn merupakan suatu nilai intensitas keabuan, sementara $\mathrm{p}(\mathrm{fn})$ menunjukkan nilai histogram (probabilitas kemunculan intensitas tersebut pada citra).

b. Variance $(\sigma 2)$

Menunjukkan variasi elemen pada histogram dari suatu citra.

$$
\sigma^{2}=\sum_{n}\left(f_{n}-\mu\right)^{2} p\left(f_{n}\right)
$$

c. Skewness ( $\alpha 3)$

Menunjukkan tingkat kemencengan relatif kurva histogram dari suatu citra.

$$
\sigma 3=1 / \sigma^{3} \sum_{n}\left(f_{n}-\mu\right)^{3} p\left(f_{n}\right)
$$

Skewness adalah derajat ketidaksimetrisan suatu distribusi. Jika kurva frekuensi suatu distribusi memiliki ekor yang lebih memanjang ke kanan (dilihat dari meannya) maka dikatakan menceng kanan (positif) dan jika sebaliknya maka menceng kiri (negatif). Secara perhitungan, skewness adalah momen ketiga terhadap mean. Distribusi normal (dan distribusi simetris lainnya, misalnya distribusi $\mathrm{t}$ atau Cauchy) memiliki skewness 0 (nol).

d. Kurtosis $(\alpha 4)$

Menunjukkan tingkat keruncingan relatif kurva histogram dari suatu citra.

$$
\sigma 4=1 / \sigma^{4} \sum_{n}\left(f_{n}-\mu\right)^{4} p\left(f_{n}\right)-3
$$

3. Ekstraksi ciri orde 2

Pada beberapa kasus, ciri orde pertama tidak lagi dapat digunakan untuk mengenali perbedaan antar citra. Pada kasus seperti ini, kita membutuhkan pengambilan ciri statistik orde dua. Salah satu teknik untuk memperoleh ciri statistik orde dua adalah dengan menghitung probabilitas hubungan ketetanggaan antara dua piksel pada jarak dan orientasi sudut tertentu. Pendekatan ini bekerja dengan membentuk sebuah matriks kookurensi dari data citra, dilanjutkan dengan menentukan ciri sebagai fungsi dari matriks antara tersebut.

Kookurensi berarti kejadian bersama, yaitu jumlah kejadian satu level nilai piksel bertetangga dengan satu level nilai piksel lain dalam jarak $(d)$ dan orientasi sudut $(\theta)$ tertentu. Jarak dinyatakan dalam piksel dan orientasi dinyatakan dalam derajat. Orientasi dibentuk dalam empat arah sudut dengan interval sudut $45^{\circ}$, yaitu $0^{\circ}, 45^{\circ}, 90^{\circ}$, dan $135^{\circ}$. Sedangkan jarak antar piksel biasanya ditetapkan sebesar 1 piksel.Matriks kookurensi merupakan matriks bujursangkar dengan jumlah elemen sebanyak kuadrat jumlah level intensitas piksel pada citra. Setiap titik $(p, q)$ pada matriks kookurensi berorientasi $\theta$ berisi peluang kejadian piksel bernilai $p$ bertetangga dengan piksel bernilai $q$ pada jarak $d$ serta orientasi $\theta$ dan $(180-\theta)$. Ciri statistik orde kedua dapat dihitung berdasarkan $\mathrm{p}(\mathrm{i}, \mathrm{j})$ dari matriks kookurensi rata-rata. Beberapa parameter ciri orde kedua, antara lain :

a. Angular second Moment

Menunjukkan ukuran sifat homogenitas citra

$$
A S M=\sum_{i} \sum_{j}\{p(i, j)\}^{2}
$$


Dimana $p(i, j)$ menyatakan nilai pada baris I dan kolom j pada matriks kookurensi.

b. Contrast

Menunjukkan ukuran penyebaran (momen inersia) elemen-elemen matriks citra. Jika letaknya jauh dari diagonal utama, nilai kekontrasan besar. Secara visual, nilai kekontrasan adalah ukuran variasi antar derajat keabuan suatu daerah citra.

$$
\begin{gathered}
C O N=\sum_{i} k^{2}\left[\sum_{i} \sum_{j}\{p(i, j)\}^{2}\right] \\
|i-j|=k
\end{gathered}
$$

c. Correlation

Menunjukkan ukuran ketergantungan linear derajat keabuan citra sehingga dapat memberikan petunjuk adanya struktur linear dalam citra.

$$
\operatorname{COR}=\left(\sum_{i} \sum_{j}(i, j) \cdot p(i, j)-\mu_{x} \mu_{y}\right) / \sigma_{x} \sigma_{y}
$$

d. Variance

Menunjukkan variasi elemen-elemen matriks kookurensi. Citra dengan transisi derajat keabuan kecil akan memiliki variansi yang kecil pula.

$$
V A R=\sum_{i} \sum_{j}\left(i-\mu_{x}\right)\left(j-\mu_{y}\right) p(i, j)
$$

e. Invers Different Moment

Menunjukkan kehomogenan citra yang berderajat keabuan sejenis. Citra homogen akan memiliki harga $I D M$ yang besar.

$$
I D M=\sum_{i} \sum_{j} \frac{1}{1+(i-j)^{2}} p(i, j)
$$

\section{f. Entropy}

Menunjukkan ukuran ketidakteraturan bentuk. Harga ENT besar untuk citra dengan transisi derajat keabuan merata dan bernilai kecil jika struktur citra tidak teratur (bervariasi).

$$
E N T_{2}=-\sum_{i} \sum_{j} p(i, j) \cdot{ }^{2} \log p(i, j)
$$

\section{F. LGCNN}

Klasifikasi merupakan proses untuk menentukan kelas dari sebuah data. Sesuai dengan objek yang diteliti, proses ini bertujuan untuk mengetahui atau mengidentifikasi jenis dari jeruk yang diinputkan kedalam sistem. Dalam proses klasifikasi terdapat banyak jenis metode klasifikasi seperti MLP, SVM, RBF dan lain-lain. Pada penelitian ini akan digunakan metode klasifikasi logarithmic generalized classifier neural network (LGCNN)[2]. Metode ini merupakan pengembangan metode sebelumnya yaitu generalized classifier neural network (GCNN) [9].

Sistem pengklasifikasi jenis jeruk dibangun sesuai dengan tahapan-tahapan yang telah ditentukan. Secara umum terdapat 4 tahapan utama dalam proses klasifikasi jenis jeruk yaitu preprocessing, segmentasi, ekstraksi fitur dan klasifikasi. Gambaran proses dapat dilihat pada Gambar 6. 


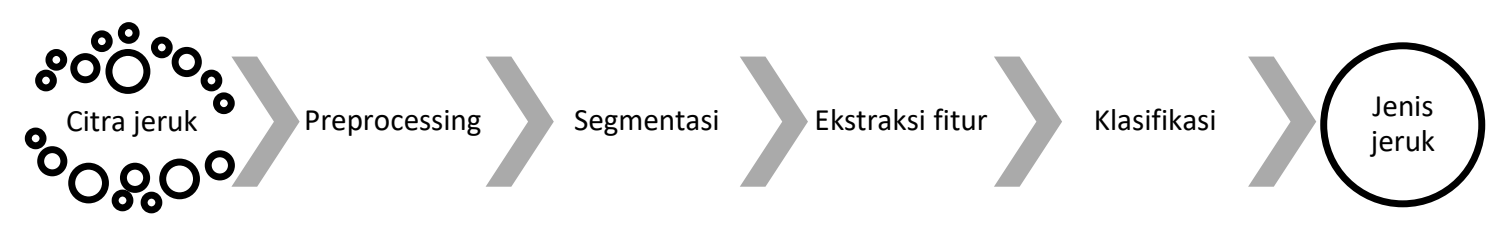

Gambar 6 Tahapan sistem klasifikasi jenis jeruk.

\section{A. Preprocessing}

Pada tahap ini dilakukan proses perbaikan citra jeruk. Tujuan dilakukan preprocessing adalah untuk standardisasi definisi warna dan memberikan perbedaan warna lebih seragam dalam kaitannya dengan perbedaan visual, sehingga dapat dilakukan proses segmentasi dengan lebih optimal. Langkah pertama adalah menentukan citra yang akan dijadikan sebagai citra input pada proses klasifikasi. Pada penelitian ini, citra input dalam ruang warna RGB dikonversi kadalam ruang warna $\mathrm{LA}^{*} \mathrm{~B} *$. tahap preprocessing dapat dilihat pada Gambar 7.

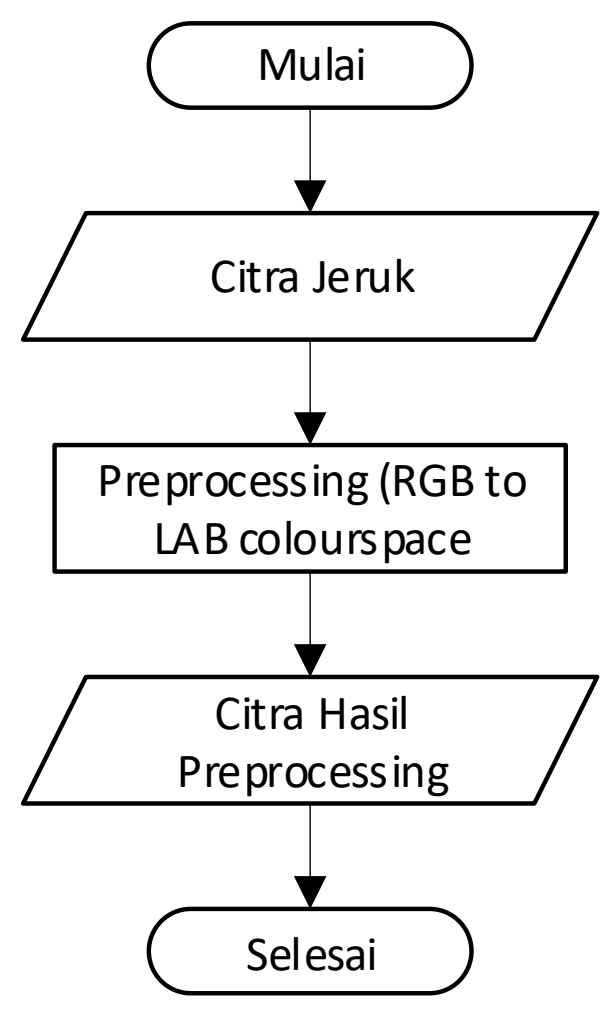

Gambar 7 Tahapan preprocessing

B. Segmentasi

Pada tahapan segmentasi dilakukan dengan menggunakan metode clustering. Pada tahapan ini citra RGB yang telah diubah kedalam LA*B* colourspace digunakan sebagai acuan untuk membedakan antara objek dan backgroundnya. Alasan digunakannya LAB dan Kmeans dalam melakukan segmentasi karena jika menggunakan otsu thresholding maka hasil segmentasi citra tidak sempurna karena adanya efek intensitas yang berbeda pada buah dan background tiap citra input [3][6]. Dengan melakukan segmentasi menggunakan K-Means pada ruang warna $\mathrm{LAB}$ hasil yang diperoleh cukup baik. Namun juga masih terdapat beberapa bagian yang tidak tersegmentasi dengan baik. Sehigga ketika dilakukan proses binarisasi perlu dilakukan operasi tambahan berupa imfill untuk mengisi bagian objek yang tidak tersegmentasi 
dengan baik dan bwareaopen untuk membuang objek kecil yang tidak diperlukan. Alur proses dapat dilihat pada Gambar 8.

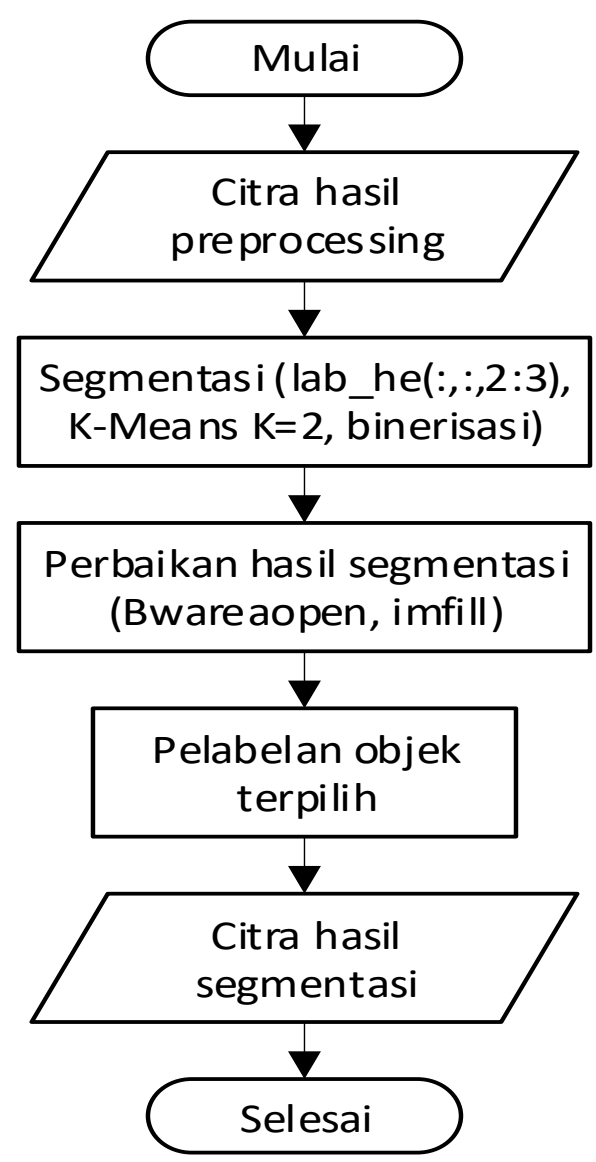

Gambar 8 Proses segmentasi

\section{Ekstraksi fitur}

Setelah mendapatkan region of interest dari hasil segmentasi maka selanjutnya dilakukan proses ekstraksfi fitur. Eksraksi fitur bertujuan untuk mengetahui fitur tiap jenis jeruk secara kuantitatif sehingga dapat dilakukan proses klasifikasi pada tahapan selanjutnya.

Pada penelitian ini terdapat tiga bagian ekstraksi fitur. Fitur pertama berupaka fitur geometric seperti circularity dan keliling dan area. Fitur kedua berupa warna yaitu mean, variance, kurtosis, dan skewness. Untuk bagian ketiga fitur diperoleh dari matrik orde 2. Sebelum melakukan perhitungan, co-occurrence matriks dihitung dengan menggunakan 4 sudut yaitu sudut $0,45,90$ dan 135 . Hasil GCLM dari ke-empat matriks tersebut kemudian dirata-ratakan. Hasil rerata kemudian digunakan sebagai acuan untuk menghitung nilai ASM, CON, COR, VAR, IDM dan ENT. Tahapan ekstraksi fitur dapat dilihat pada Gambar 9. 


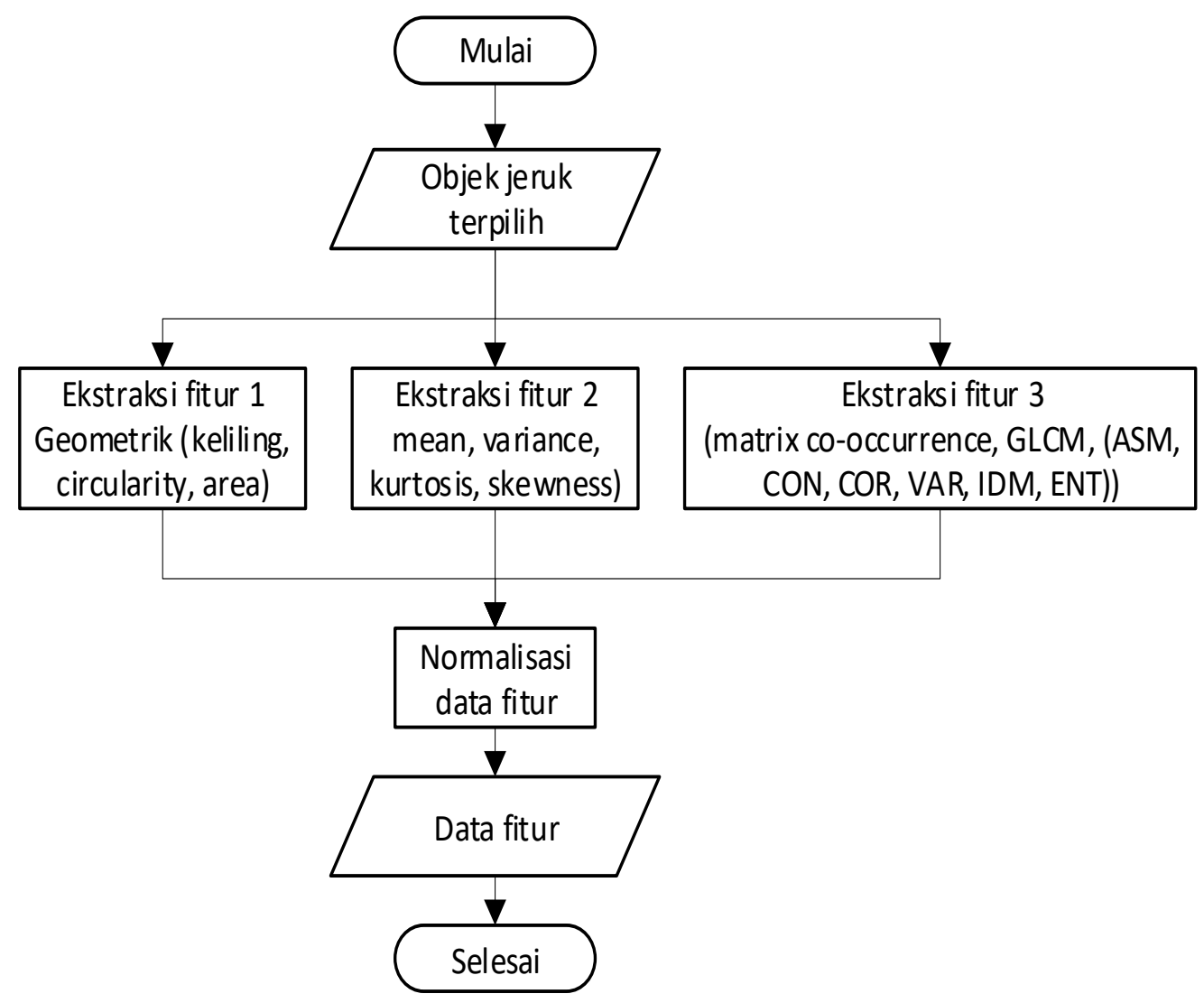

Gambar 9 Proses ekstraksi fitur

\section{Klasifikasi}

Klasifikasi merupakan proses untuk menentukan kelas dari sebuah data. Sesuai dengan objek yang diteliti, proses ini bertujuan untuk mengetahui atau mengidentifikasi jenis dari jeruk yang diinputkan kedalam sistem. Pada penelitian ini akan digunakan metode klasifikasi logarithmic generalized classifier neural network (LGCNN) [2]. Pada tahapan klasifikasi, data fitur yang telah diperoleh pada tahapan sebelumnya dijadikan acuan untuk mengklasifikasikan jenis jeruk. Sebelum melakukan klasifikasi terhadap data uji, diperlukan proses pelatihan jaringan terlebih dahulu dengan menggunakan data-data latih yang ada. Gambaran proses klasfikasi dapat dilihat pada Gambar 10. 


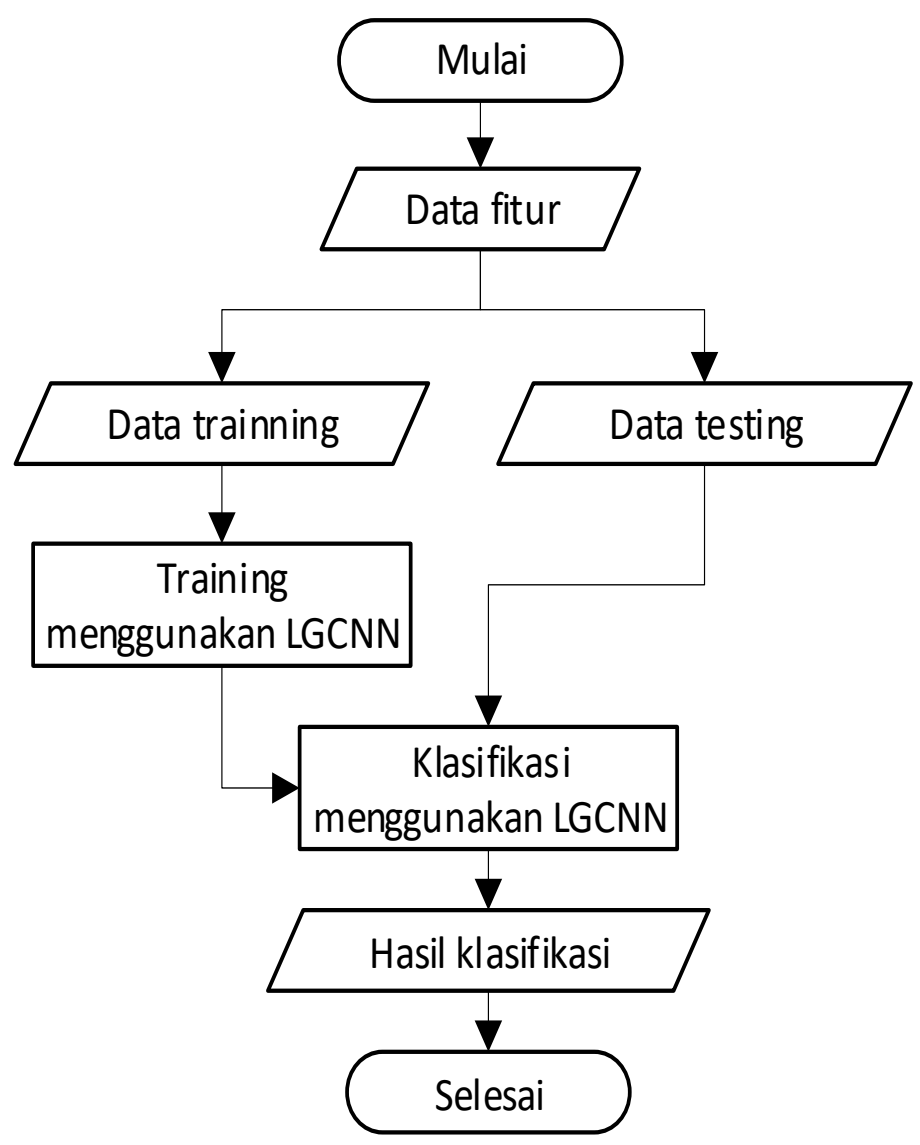

Gambar 10 Proses klasifikasi

\section{HASIL DAN PEMBAHASAN}

Untuk mengetahui keberhasilan pada sistem yang diusulkan maka dilakukan uji coba terhadap sistem yang diusulkan. Uji coba dilakukan dengan menggunakan data uji coba berupa gambar jeruk dengan 4 jenis jeruk yaitu jeruk ponkam, navel, valencia dan sanatang. Setiap jeruk digunakan sebanyak 20 sampel gambar, sehingga 4 jenis jeruk terdapat 80 sampel gambar jeruk. Uji coba dilakukan dengan beberapa tahapan, adapun tahapan-tahapan tersebut adalah sebagai berikut.

A. Hasil uji coba menggunakan fitur geometric dan metode LGCNN

Pada tahap ini dilakukan uji coba dengan menggunakan beberapa fitur geometrik seperti fitur area, fitur sifat bundar, fitur keliling dan semua fitur yang digabung (fitur area, fitur sifat bundar, dan fitur keliling). Untuk klasifikasi pada tahap ini digunakan metode LGCNN. Adapun hasil akurasi pada uji coba ini dapat dilihat pada Tabel 1.

Tabel 1 Akurasi fitur geometrik dan LGCNN

\begin{tabular}{|c|c|c|c|}
\hline \multicolumn{4}{|c|}{ Penggunaan Fitur } \\
\hline Area & Sifat bundar & Keliling & Semua fitur \\
\hline $93.75 \%$ & $61.25 \%$ & $95.00 \%$ & $95.00 \%$ \\
\hline
\end{tabular}


B. Hasil uji coba menggunakan fitur statistik warna RGB dan LGCNN

Pada tahap ini dilakukan uji coba dengan menggunakan beberapa fitur statistik pada ruang warna RGB. Adapun fitur yang diuji coba adalah fitur mean, STDEV, Skewness, Kurtosis dan semua fitur dari fitur (mean, STDEV, skewness dan kurtosis). Untuk metode klasifikasi yang digunakan adalah metode LGCNN. Adapun hasil akurasi dari uji coba ini dapat dilihat pada Tabel 2.

Tabel 2 Akurasi fitur warna RGB dan LGCNN

\begin{tabular}{|c|c|c|c|c|}
\hline \multicolumn{5}{|c|}{ Penggunaan Fitur } \\
\hline Mean & STDEV & Skewness & Kurtosis & Semua fitur \\
\hline $67.50 \%$ & $95.00 \%$ & $87.50 \%$ & $70.00 \%$ & $80.00 \%$ \\
\hline
\end{tabular}

C. Hasil uji coba menggunakan fitur statistik warna La*b* dan LGCNN

Pada tahap ini dilakukan uji coba dengan menggunakan beberapa fitur statistik pada ruang warna $\mathrm{La}^{*} \mathrm{~b}^{*}$. Adapun fitur yang diuji coba adalah fitur mean, STDEV, skewness, kurtosis dan semua fitur dari fitur (mean, STDEV, skewness dan kurtosis). Untuk metode klasifikasi yang digunakan adalah metode LGCNN. Adapun hasil akurasi dari uji coba ini dapat dilihat pada Tabel 3 .

Tabel 3 Akurasi fitur warna La*b* dan LGCNN

\begin{tabular}{|c|c|c|c|c|}
\hline \multicolumn{5}{|c|}{ Penggunaan Fitur } \\
\hline Mean & STDEV & Skewness & Kurtosis & Semua fitur \\
\hline $63.70 \%$ & $90.00 \%$ & $83.75 \%$ & $75.50 \%$ & $85.00 \%$ \\
\hline
\end{tabular}

D. Hasil uji coba menggunakan fitur Orde dua dan LGCNN

Pada tahap ini dilakukan uji coba dengan menggunakan beberapa fitur warna orde dua. Adapun fitur yang diuji coba adalah fitur ASM, CON, COR, VAR, IDM, ENT dan semua fitur dari fitur (ASM, CON, COR, VAR, IDM dan ENT). Untuk metode klasifikasi yang digunakan adalah metode LGCNN. Adapun hasil akurasi dari uji coba ini dapat dilihat pada Tabel 4.

Tabel 4 Akurasi fitur warna orde dua dan LGCNN

\begin{tabular}{|c|c|c|c|c|c|c|}
\hline \multicolumn{7}{|c|}{ Penggunaan Fitur 4 } \\
\hline ASM & CON & COR & VAR & IDM & ENT & Semua fitur \\
\hline $67.50 \%$ & $88.75 \%$ & $90.00 \%$ & $58.75 \%$ & $57.50 \%$ & $62.50 \%$ & $86.25 \%$ \\
\hline
\end{tabular}

E. Hasil uji coba menggunakan semua fitur dan LGCNN

Pada tahap ini dilakukan uji coba dengan menggunakan semua fitur. Fitur yang digunakan adalah fitur geometrik, fitur statistik pada ruang warna RGB, fitur statistik pada ruang warna $\mathrm{La}^{*} \mathrm{~b}^{*}$ dan fitur warna orde dua. Untuk metode klasifikasi yang digunakan adalah metode LGCNN. Adapun hasil akurasi dari uji coba ini dapat dilihat pada Tabel 5.

Tabel 5 Akurasi semua fitur dan LGCNN

\begin{tabular}{|c|}
\hline Semua fitur \\
\hline $95.75 \%$ \\
\hline
\end{tabular}

Dari hasil uji coba yang telah dilakukan menunjukkan bahwa akurasi pada hasil klasifikasi dengan menggunakan fitur geometrik dan metode klasifikasi LGCNN memiliki tingkat akurasi cukup baik dengan tingkat kaurasi 95.00\%. Sedangkan hasil uji coba dengan 
menggunakan semua fitur (fitur geometrik, fitur statistik pada ruang warna RGB, fitur statistik pada ruang warna La*b* dan fitur warna orde dua) dan metode klasifikasi LGCNN memiliki tingkat akurasi lebih baik dibandingkan dengan menggunakan fitur geometrik dan fitur lainnya yaitu dengan tingkat akurasi $95.75 \%$.

\section{KESIMPULAN}

Dari hasil penelitian dan uji coba terhadap sistem yang telah dilakukan dapat disimpulkan sebagai berikut.

a. Sistem yang diusulkan adalah sistem klasifikasi jenis jeruk impor dengan menggunakan fitur geometrik, fitur statistik pada ruang warna $\mathrm{La}^{*} \mathrm{~b}^{*}$, fitur warna orde dua dan metode klasifikasi LGCNN.

b. Uji coba dilakukan dengan menggunakan 4 jenis jeruk dan 20 sampel gambar pada setiap jenis jeruk.

c. Hasil uji coba dengan menggunakan fitur-fitur geometrik dan metode klasifikasi LGCNN memiliki akurasi $95.00 \%$.

d. Hasil uji coba dengan menggunakan fitur-fitur statistik pada ruang warna RGB dan metode klasifikasi LGCNN memiliki akurasi $80.00 \%$.

e. Hasil uji coba dengan menggunakan fitur-fitur statistik pada ruang warna $\mathrm{La}^{*} \mathrm{~b}^{*}$ dan metode klasifikasi LGCNN memiliki akurasi $85.00 \%$.

f. Hasil uji coba dengan menggunakan fitur-fitur warna orde dua dan metode klasifikasi LGCNN memiliki akurasi $86.25 \%$.

g. Hasil uji coba dengan menggunakan semua fitur dan metode klasifikasi LGCNN memiliki akurasi yang paling tinggi yaitu $95.75 \%$.

h. Dari beberapa hasil uji coba yang dilakukan menunjukkan bahwa sistem yang diusulkan dengan menggunakan fitur geometrik, fitur statistik pada ruang warna $\mathrm{La}^{*} \mathrm{~b}^{*}$, fitur warna orde dua dan metode klasifikasi LGCNN dapat mengklasifikasikan jenis jeruk impor dengan akurasi tertinggi $95.75 \%$.

\section{SARAN}

Pada penelitian ini sistem yang diusulkan hanya dapat mengklasifikasikan jenis jeruk berdasakan bentuk dan warna, sehingga ketika jenis jeruk memiliki bentuk dan warna yang sama maka sulit untuk membedakan jenis jeruk tersebut. Saran penulis untuk pengembangan penelitian ini adalah dengan menambah fitur tekstur. Selain itu, penggunaan metode klasifikasi LGCNN ketika digunakan pada banyak kelas maka akan terjadi overfitting atau sulit untuk menentukan kelas, oleh karena itu, perlu dilakukan perbandingan dengan metode klasifikasi yang lain seperti KNN, SVM dan lain-lain.

\section{DAFTAR PUSTAKA}

[1] R. Sumithra, M. Suhil, and D. S. Guru, "Segmentation and Classification of Skin Lesions for Disease Diagnosis," Procedia Comput. Sci., vol. 45, pp. 76-85, 2015.

[2] B. Melis and M. Avci, "Logarithmic learning for generalized classifier neural network," Neural Networks, vol. 60, pp. 133-140, 2014.

[3] L. Busin, N. Vandenbroucke, and L. Macaire, Color Spaces and Image Segmentation, vol. 151, no. 07. Elsevier Masson SAS, 2008.

[4] a. Camargo and J. S. Smith, "An image-processing based algorithm to automatically identify plant disease visual symptoms," Biosyst. Eng., vol. 102, no. 1, pp. 9-21, 2009.

[5] N. Otsu, "“A Threshold Select[1] N. Otsu, "“A Threshold Selection Method from GrayLevel Histograms," IEEE Trans. Syst. MAN, Cybern., vol. C, no. 1, pp. 62-66, 1979.ion Method from Gray-Level Histograms," IEEE Trans. Syst. MAN, Cybern., vol. 
C, no. 1, pp. 62-66, 1979.

[6] T. Chen, Y. Chen, and S. Chien, "Fast image segmentation based on K-Means clustering with histograms in HSV color space," 2008 IEEE 10th Work. Multimed. Signal Process., pp. 322-325, 2008.

[7] J. Pang, Z. Y. Bai, J. C. Lai, and S. K. Li, "Automatic segmentation of crop leaf spot disease images by integrating local threshold and seeded region growing," Proc. 2011 Int. Conf. Image Anal. Signal Process. IASP 2011, pp. 590-594, 2011.

[8] H. Yao, Q. Duan, D. Li, and J. Wang, “"An Improved K -means Clustering Algorithm for Fish Image Segmentation," Math. Comput. Model., vol. 58, no. 3-4, pp. 790-798, 2013.

[9] B. M. Ozyildirim and M. Avci, "Generalized classifier neural network," Neural Networks, vol. 39, pp. 18-26, 2013. 